\title{
Pengaruh tambahan ekstrak minyak tuna pada umpan bubu paralon terhadap hasil tangkapan ikan-ikan karang
}

\author{
The effect of tuna oil extract added to bait of paralon traps on catching reef fish \\ JOHN PIETER MAINAKE*, EMIL REPPIE dan AGLIUS T.R.TELLENG \\ Program Studi Pemanfaatan Sumberdaya Perikanan, Fakultas Perikanan dan Ilmu Kelautan, \\ Universitas Sam Ratulangi, Manado 95115
}

\begin{abstract}
Various traps have been used world-wide, but the basic concept is similar in all cases that fish or other sea animals will get into the trap through one or more cone-shaped doors. The success of baited traps is largely determined by the activity of fish to find and catch food. Adding oil tuna to the bait could increase the fishing power of paralon trap. The objective of this research was to study the effect of tuna oil added to bait in paralon trap on catching coral fish. This research was done in Lembeh Strait based on experimental method. Six units of paralon trap were operated within ten nights; where tree units of them used scads mackerel bait injected with tuna oil, and the other three used scads mackerel bait without tuna oil; and the capture data were analyzed using $t$ test. The total catch was 75 fish consisted of 14 families, 23 genera and 36 species; 45 fish were caught in trap with tuna oil added bait, and 30 fishes were caught in trap with plain bait. Analysis of $t$ test shows that the addition of tuna oil on bait increased the catch of paralon trap.
\end{abstract}

Keywords: paralon trap, tuna oil, baits, coral fishes, Lembeh Strait

\begin{abstract}
ABSTRAK
Alat tangkap bubu telah digunakan dengan sangat beragam di seluruh dunia, tetapi konsep dasarnya adalah sama pada semua kasus di mana ikan atau hewan laut lainnya akan masuk ke dalam bubu melalui satu atau lebih pintu yang berbentuk kerucut. Keberhasilan alat tangkap bubu berumpan sangat ditentukan oleh aktivitas hidup ikan dalam hal mencari dan menangkap makanan. Pemberian ekstrak minyak ikan tuna pada umpan bubu paralon, diduga dapat meningkatkan hasil tangkapan. Penelitian ini bertujuan untuk mempelajari pengaruh pemberian ekstrak minyak tuna pada umpan bubu paralon terhadap hasil tangkapan ikan-ikan karang. Penelitian ini dilakukan di perairan Selat Lembeh Kota Bitung; yang didasarkan pada metode eksperimental. Enam unit bubu paralon dioperasikan selama 10 malam untuk mengumpulkan data; dimana tiga unit bubu menggunakan umpan ikan layang yang disuntik dengan minyak ikan tuna, dan tiga unit lainnya menggunakan umpan ikan layang tanpa minyak ikan tuna; dan data tangkapan dianalisis dengan uji $t$. Tangkapan total berjumlah 75 ekor yang terdiri dari 14 famili, 23 genus dan 36 spesies; 45 ekor tertangkap pada umpan layang dengan minyak ikan tuna, dan 30 ekor tertangkap pada umpan layang tanpa minyak ikan tuna. Hasil analisis uji $t$ menunjukan bahwa umpan bubu paralon yang diberi ekstrak minyak tuna menghasilkan tangkapan yang lebih baik dibandingkan dengan umpan tanpa ekstrak.
\end{abstract}

Kata-kata kunci: bubu paralon, minyak ikan tuna, umpan, ikan karang, Selat Lembeh.

\section{PENDAHULUAN}

Perairan terumbu karang merupakan jenis ekosistem yang sangat penting di perairan pantai daerah tropis seperti Indonesia, karena ekosistem ini mempunyai produktivitas primer yang sangat

\footnotetext{
* Penulis untuk penyuratan; email: johnmainake1012@gmail.com
}

tinggi. Tingginya produktivitas primer di daerah tersebut, menyebabkan produktivitas perikanannya juga menjadi tinggi pula; sehingga perairan karang biasanya menjadi sasaran utama aktivitas perikanan dari sebagian besar masyarakat pesisir, yang hidupnya hanya bergantung pada sumberdaya terumbu karang tersebut (Reppie dan Labaro, 2008). 